How to reference this article Miszalska, J. (2015). Wenecki "libertyn" Giovan Francesco Loredano w biografiach autorstwa współczesnych mu literatów. Italica Wratislaviensia, 6, 355-361.

DOI: http://dx.doi.org/10.15804/IW.2015.06.25

Jadwiga Miszalska

Uniwersytet Jagielloński

jadwiga.miszalska@uj.edu.pl

\title{
WENECKI „LIBERTYN” GIOVAN FRANCESCO LOREDANO W BIOGRAFIACH AUTORSTWA WSPÓŁCZESNYCH MU LITERATÓW
}

Lucinda Spera (2014). Due biografie per il principe degli Incogniti. Edizione e commento della „Vita di Giovan Francesco Loredano” di Gaudenzio Brunacci (1662) e di Antonio Lupis (1663). Bologna: Ed. Libri di Emil, pp. 166.

$\mathrm{L}$ ucinda Spera, profesor na Università per Stranieri w Sienie, jest znaną badaczką literatury włoskiej wieku XVII. W swych studiach publikowanych na łamach czasopism włoskich i zagranicznych poświęciła szczególną uwagę kulturze literackiej Seicenta w jej przejawach popularnych. Zajmowały ją w szczególności strategie autorskie i wydawnicze mające na celu zapewnienie produkcji literackiej nie tylko artystycznego, ale i komercyjnego sukcesu. Jednym z gatunków, który zyskuje na popularności w wieku XVII i staje się źródłem dochodów autorów i wydawców, jest romans (powieść) prozą. O różnych aspektach twórczości powieściowej i nowelistycznej włoskiego baroku Lucinda 
Spera pisała m.in. w monografiach Il romanzo italiano del tardo Seicento ${ }^{1}$ i Verso il moderno. Pubblico immaginario nel Seicento italia$n o^{2}$. Obecnie ukazała się jej nowa książka dotycząca tej problematyki. W serii „Biblioteca del Rinascimento e del Barocco” opublikowała dwie biografie Giovan Francesca Loredana napisane i wydane tuż po jego śmierci w roku 1662 i 1663. Biografie poprzedzone są obszernym wstępem i opatrzone przypisami, a całości dopełnia indeks osób.

Giovan Francesco Loredano dziś znany jest jedynie badaczom kultury literackiej wieku XVII. Pisarz, baczny obserwator wydarzeń swej epoki, thumacz popularnych autorów, mecenas i protektor początkujących twórców, współwydawca zakazanych pism, twórca jednej z bardziej znaczących włoskich siedemnastowiecznych akademii, Accademia degli Incogniti (1630-1661), był jednym z ważniejszych przedstawicieli kultury weneckiej pierwszej połowy wieku XVII. Urodził się w roku $1606 \mathrm{w}$ rodzinie zamożnych i szanowanych patrycjuszy weneckich. Wydał pierwszy swój utwór De gli scherzi geniali już w 1623 r. w wieku zaledwie szesnastu lat. Utwór w ciągu miesiąca rozszedł się w nakładzie 3000 egzemplarzy, co stawiało go przed wydanym w tym samym roku Adonisem Marina.

Całe swe dorosłe życie poświęcił Loredano dwóm pasjom: polityce i literaturze. W tej pierwszej nie doszedł jednak do znaczących funkcji. Wprawdzie przez pewien czas był nawet członkiem Rady Dziesięciu, ale kariera jego zakończyła się rodzajem wygnania, jakim było piastowanie funkcji zarządcy w fortecy w Peschiera $\mathrm{z}$ dala od Wenecji i od ukochanej posiadłości na lądzie Vigodarzere. Dużo bardziej owocna okazała się druga sfera jego działalności, jako że Loredano stał się jednym z bardziej poczytnych autorów weneckich tego okresu.

Jak wielu autorów jego epoki, określanych przez włoskich historyków literatury mianem poligrafi, imał się on różnych rodzajów pisarstwa. Napisał dwa romanse, sentymentalno-przygodową Dianeę

1 Spera, L. (2000). Il romanzo italiano del tardo Seicento. Milano: La Nuova Italia.

Spera, L. (2008). Verso il moderno. Pubblico immaginario nel Seicento italiano. Roma: Carocci. 
(1635) i Adama (1640) o tematyce religijnej; pisał też nowele: Le novelle amorose, biografie: Vita del cavalier Marino, Vita di Alessandro III, pisma historyczne: Historia dei re Lusignani, polityczne: La morte di Volestein, utwory żartobliwe: De gli scherzi geniali, Iliade giocosa oraz dewocyjne: Sensi di devozione, Gradi dell'anima, a także listy: Lettere. Warto wspomnieć, że Dianea na przestrzeni pięćdziesięciu lat miała we Włoszech około dwudziestu wydań, a młodzieńcze Scherzi do roku 1659 ukazały się aż dwadzieścia siedem razy. Literatura stała się dla niego sposobem na zaistnienie w społeczności weneckiej. Takimi słowami zwracał się do Leonarda Queriniego: „Bisogna scrivere, signor mio, chi ama l'eternità della fama e la distinzione tra gli uomini. Come l'uomo si distingue col parlare dagli altri animali, così con lo scrivere dagli altri uomini” [Trzeba pisać, mój panie, jeśli ktoś miłuje wieczną sławę i znaczenie wśród ludzi. Tak jak od zwierząt człowiek różni się mową, tak od innych ludzi pisaniem]³.

Utwory Loredana zyskały ogromną poczytność nie tylko w Italii. Były czytane w oryginale i przekładane w wielu krajach Europy. Ograniczając się jedynie do romansów, możemy stwierdzić, że Dianea została przełożona na język francuski (1642), angielski (1654), niemiecki (1644, 1671), a Adamo otrzymał szatę francuską (1646, 1695, 1696, wyd. s.d.), angielską (1654, 1748, 1811), hiszpańską (1657) i niemiecką $(1703)^{4}$. W recepcji Loredana odnajdujemy też silny akcent polski, bowiem aktualnie udało się odnaleźć w naszych bibliotekach około osiemdziesięciu pięciu egzemplarzy jego dzieł. Są to prawie wszystkie utwory tego autora: dzieła zebrane czyli, Opere, listy (Lettere), Dianea, Adamo, Historia dei re Lusignani, Iliade giocosa, Bizzarie accademiche, Scherzi geniali, Novelle amorose, Sei dubbi

3 Cyt. za Mattozzi, I. (1966). Nota su Giovan Francesco Loredano. Studi Urbinati, n. 1, 257-288 (p. 267).

4 Dane na podstawie: Gori, M. (1993). Il romanzo italiano del Seicento. Rassegna bibliografica. La rassegna della letteratura italiana, n. 3, 130-132; Mancini, A.N. (1970). Il romanzo nel Seicento. Saggio di bibliografia. Studi secenteschi, 11, 205-274; Mancini, A. N. (1971). Il romanzo nel Seicento. Saggio di bibliografia. Studi secenteschi, 12, 443-498; Mancini, A.N. (1975). Il romanzo italiano nel Seicento. Saggio di bibliografia delle traduzioni in lingua straniera. Studi secenteschi, 16, 193-217. 
amorosi, Sensi di devozione, Vita di Alessandro III. Wśród utworów tych znajdują się niemieckie i francuskie przekłady Listów, Adama, Dianei. Warto również przyjrzeć się datom wydania tych utworów. Dziesięć wydań pochodzi sprzed roku 1650: drugie wydanie Opere z 1649 r., pierwodruk Adamo z 1640 r., dość wczesna edycja Bizzarie z 1640 r. (pierwodruk 1638) oraz - co ciekawe - wydanie Sensi di devozione z 1634 r., podczas gdy źródła włoskie notują jako najstarszą edycję tę z roku 1639.

O znajomości Loredana w naszym kraju świadczy wzmianka w dialogu Rozmowy Artaksesa i Ewandra S.H. Lubomirskiego (1676). Marszałek koronny pomiędzy utworami będącymi przykładem pięknego stylu wspomina Lettere, nieco dalej cytując Dianeę wraz z innymi modnymi romansami. Najbardziej namacalnym dowodem polskiej recepcji pisarza są przekłady. Na język polski przełożono cztery jego utwory. Tłumaczenia te można podzielić na dwie grupy, przyjmując kryterium chronologiczne. Trzy utwory zostały przełożone w połowie wieku XVII, a tłumaczem był Krzysztof Piekarski, znany głównie z polskiej wersji przygód kapitana Spaventy Francesca Andreiniego. Piekarski przełożył romans biblijny Adamo oraz dwa dziełka dewocyjne Gradi dell'anima i Sensi di devozione, wydając je pod wspólnym tytułem Suplik zbawiennych piętnaście. Co ważne, polski Adam był drugim przekładem w Europie po francuskim, pochodzącym z roku 1646. Drugi etap zainteresowania twórczością Loredana przypada na I połowę wieku XVIII i dotyczy jego najsłynniejszego utworu, Dianei. W Polsce w tym czasie powstały trzy przekłady tej powieści: dwie wersje wierszowane autorstwa anonima i Kazimierza Dominika Ogińskiego oraz jedna prozaiczna Barbary Radziwiłłowej. Wszystkie trzy wersje zachowały się w pojedynczych kopiach rękopiśmiennych. Pomiędzy tymi dwiema grupami sytuuje się jeszcze jeden przekład: jest to czwarta wersja Dianei zachowana w rękopisie o niepewnym datowaniu. Jej autorem był Paweł Załuski, utożsamiany z sufraganem płockim lub profesorem retoryki w Akademii Krakowskiej, aktywnym w latach czterdziestych XVII stulecia.

Książka Lucindy Spery jest pozycją, która rzuca dodatkowe światło na postać weneckiego patrycjusza. Okazuje się, że chociaż był on 
postacią znaną, a nawet sławną w swej epoce, wiele faktów z jego życia okryte jest mgłą. Już wkrótce po śmierci, która zabrała go zbyt wcześnie w roku 1661, doczekał się dwóch biografii. Czy jednak biografie te poszerzają wiedzę na temat tego autora? Na pierwszy rzut oka wydaje się, że niewiele. We wstępie Autorka proponuje nam jednakże pewien klucz lektury obu tekstów, pozwalający zrozumieć to, co nie zostaje powiedziane wprost.

Autorami obu biografii są młodzi literaci, którzy w ostatnich latach życia Loredana korzystali z jego wpływów i kontaktów, jak jednak twierdzi Spera, żadna z nich nie została zamówiona przez Akademików Incogniti jako oficjalna biografia „księcia” Akademii. Świadczyłoby to o utracie znaczenia tego gremium, które swe lata świetności miało już za sobą, a także o niepewnej pozycji politycznej Loredana „zesłanego" do Peschiery. Interesujące jest, że dwa te druki, których autorzy ze sobą korespondowali i, jak się wydaje, nie rywalizowali, sporządzone są według nieco innych reguł retorycznych i oddają różnice $\mathrm{w}$ ich relacjach $\mathrm{z}$ protektorem. W istocie $\mathrm{w}$ wieku XVII biografia jako gatunek przejawiała silne związki z formami klasycznymi takimi jak: historiografia, epistolografia, elogium czy pisma dydaktyczno-moralizatorskie. Tak więc biografistyka mogła realizować różne warianty w zależności od pozycji swego autora, jego przynależności do konkretnego środowiska, relacji z opisywaną postacią czy funkcji, jaką przypisywał swemu dziełu.

Gaudenzio Brunacci, urodzony w 1631 r., był cenionym lekarzem o ambicjach literackich. Znajomość z Loredanem miała mu pomóc w wydaniu powieści Sofonisba (1661). Po śmierci protektora Brunacci poświęca się praktyce i pracy naukowej, publikując głównie teksty medyczne. W swej biografii Brunacci wydaje się wzorować głównie na antycznych historykach i filozofach: Plutarchu, Diogenesie Laertiusie, Tacycie i Senece. Informacje na temat Loredana czerpie natomiast z licznych pism Wenecjanina, w których już wcześniej pojawiały się jego panegiryczne portrety. Pisząc biografię, Brunacci pozostawał niejako na zewnątrz środowiska Incogniti, a ze swym protektorem miał kontakty raczej luźne. To sprawia, że wykreowany przez niego portret Loredana cechuje pewien „obiektywizm”, a jed- 
nocześnie schematyzm: biograf $\mathrm{w}$ istocie korzysta obficie $\mathrm{z}$ topiki mitologicznej. Gdy jednak zatrzymamy się chwilę nad niektórymi sformułowaniami - twierdzi Autorka - mamy wrażenie, że odsyłają one do pewnych faktów dotyczących protagonisty tekstu, nie zawsze chlubnych, a wspominanych w krążących anegdotach.

Inna była pozycja społeczna Antonia Lupisa, o którym wiemy mniej. Nie znamy jego daty urodzenia, ale prawdopodobnie była to połowa lat 30. Pochodził z Molfetty, którą musiał opuścić z nie do końca wyjaśnionej przyczyny, być może z powodu jakiegoś procesu sądowego czy podejrzeń o uprawianie magii. W Wenecji jedynym pewnym punktem odniesienia jest dla niego Loredano, przy którym pełni funkcję sekretarza, wszędzie mu towarzysząc. Lupis pozostaje z Loredanem aż do ostatnich chwil jego życia i sprawia wrażenie szczerze przywiązanego do swego protektora, któremu zawdzięcza początki swej dość bogatej kariery literackiej (pierwsza powieść La Faustina ukazała się w roku 1660 - tak jak i Sofonisba Brunacciego - u Valvasensego, z którym Loredano współpracował). Ta bliska relacja z Loredanem wyłania się z tekstu Lupisa, dostarcza on bowiem szczegółów, które mógł znać tylko ktoś pozostający w zażyłości z pisarzem; opisuje on dokładnie ostatnie chwile „księcia” Akademii, jego chorobę i śmierć. Nie zmienia to faktu, że Lupis, podobnie jak Brunacci, nie odsłania pewnych faktów, które mogłyby w jakikolwiek sposób naruszyć idealny portret protagonisty. Nie dowiadujemy się zatem z biografii, co było bezpośrednią przyczyną odsunięcia Loredana od ważnych stanowisk i powierzenia mu mało zaszczytnej funkcji komendanta twierdzy Peschiera.

W konkluzji wstępu Lucinda Spera zastanawia się, czy któraś z dwóch biografii mogłaby zostać uznana za oficjalny portret Mistrza i dochodzi do wniosku, że autorami powodowały raczej motywy osobiste. Była to wdzięczność dla protektora ich pierwszych prób literackich, nadzieja znalezienia wsparcia w kręgach jego przyjaciół, a może chodziło też o pewną ,grę luster”, w trakcie której postać mniej znana (autor biografii) staje się w pewnym sensie uczestnikiem chwały swego protagonisty, pośrednikiem między nim a zwykłym czytelnikiem. 
Opracowanie Lucindy Spery jest ciekawe nie tylko ze względu na informacje o weneckim środowisku Incogniti i samym Loredanie, jakie Autorka zamieszcza we wstępie i przypisach, ale przede wszystkim dlatego, że przybliża nam relacje łączące protagonistów tamtej epoki, odkrywa pewne mechanizmy rządzące światem elit kulturalnych i politycznych. Polskiego czytelnika zachęca też do szukania odpowiedzi na pytanie, jaki charakter miała polska recepcja weneckiego „libertyna”, gdyż wiedza na ten temat wydaje się jeszcze bardzo niepełna. 